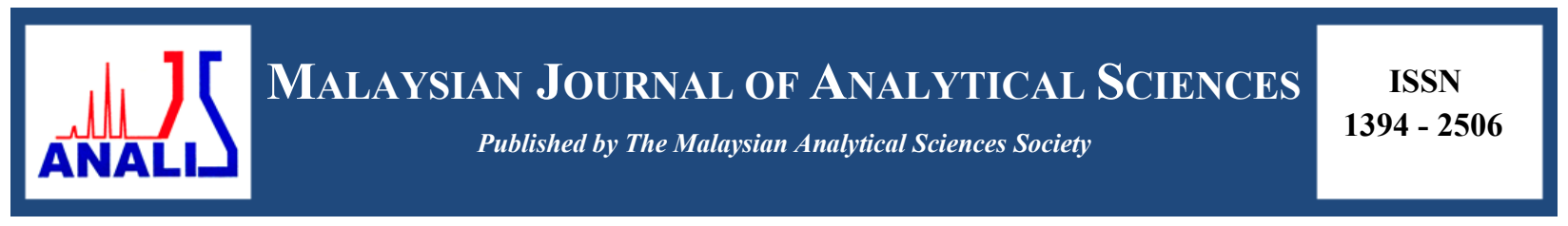

\title{
EFFECT OF HEAT TREATMENTS ON THE YIELD, QUALITY AND STORAGE STABILITY OF OIL EXTRACTED FROM PALM FRUITS
}

\author{
(Kesan Rawatan Haba Terhadap Peratus Pengekstrakan Minyak, Kualiti dan Kestabilan Semasa \\ Penyimpanan Minyak yang Diekstrak Daripada Buah Kelapa Sawit) \\ Hasimah Kasmin ${ }^{1,2}$, Azwan Mat Lazim², Roila Awang ${ }^{1 *}$ \\ ${ }^{I}$ Engineering \& Processing Research Division, \\ Malaysian Palm Oil Board, No. 6, Persiaran Institusi, Bandar Baru Bangi, 43000 Kajang, Selangor, Malaysia \\ ${ }^{2}$ School of Chemical Sciences and Food Technology, Faculty of Science and Technology, \\ Universiti Kebangsaan Malaysia, 43600 UKM Bangi, Selangor, Malaysia \\ *Corresponding author: roila@mpob.gov.my
}

Received: 17 August 2015; Accepted: 29 August 2016

\begin{abstract}
This paper presents the impact of heat treatments on the yield and quality of the palm oil using solvent extraction techniques. Heating temperature range from 70 to $90{ }^{\circ} \mathrm{C}$ and heating time range from 30 to 90 min were studied. The quality parameters measured were free fatty acids (FFA), deterioration of bleaching index (DOBI), carotene content, oxidative stability and fatty acid composition of the oil. These parameters were used to determine CPO quality which has been stored for 3 months. It was found that the yield significantly increased with the increasing of heating temperature and time. The optimum parameter was achieved with heating temperature of $90{ }^{\circ} \mathrm{C}$ and heating time of $60 \mathrm{~min}$ via wet heating. Optimum oil yield obtained was $24 \%$ with $0.93 \%$ FFA content, 6.10 DOBI, 938.42 ppm carotene content and oxidative stability of 26.87 hours. Fatty acid composition (FAC) of oil extracted showed a reduction in unsaturated fatty acids as the heating duration increased. After 3 months of storage, $60 \mathrm{~min}$ of heating time via wet heating process was recorded the lowest increment of FFA (1.32\%) and low reduction of DOBI value (0.41). However, carotene content gave the highest loss with $113.54 \mathrm{ppm}$ towards the end of the storage.
\end{abstract}

Keywords: crude palm oil, heat treatments, oil yield, oil quality, storage stability

\begin{abstract}
Abstrak
Kajian ini bertujuan untuk menganalisis kesan rawatan haba semasa pensterilan ke atas peratus pengekstrakan minyak dan kualiti minyak sawit mentah (MSM) dengan menggunakan pelarut bagi mengekstrak MSM. Suhu dan masa pensterilan yang berlainan telah digunakan bagi mengekstrak MSM iaitu suhu pensterilan dari 70 hingga $90{ }^{\circ} \mathrm{C}$ manakala masa pensterilan dari 30 hingga 90 min. Kesan rawatan haba ke atas peratus pengekstrakan minyak telah dijalankan. Kualiti MSM yang diekstrak iaitu asid lemak bebas (ALB), indeks pemerosotan terhadap pelunturan (DOBI), kandungan karotena, kestabilan oksidatif dan komposisi asid lemak telah dicirikan. Parameter ini digunakan untuk menentukan kualiti MSM yang telah disimpan selama 3 bulan. Hasil kajian mendapati peratus pengekstrakan minyak meningkat secara signifikan dengan kenaikkan suhu dan masa. Hasil optimum pada tahap maksimum iaitu sebanyak 24\% telah dicapai pada suhu pensterilan $90{ }^{\circ} \mathrm{C}$ dan masa pensterilan 60 min dengan menggunakan pemanasan basah. Kualiti minyak pula menunjukkan kandungan ALB sebanyak 0.93\%, DOBI sebanyak 6.10, kandungan karotena sebanyak 938.42 ppm dan kestabilan oksidatif selama 26.87 jam. Selepas 3 bulan penyimpanan, masa pemanasan selama 60 min menggunakan pemanasan basah telah menunjukkan peningkatan kandungan ALB dan penurunan bacaan DOBI yang paling rendah iaitu masing-masing $1.32 \%$ dan 0.41 . Namun, kandungan karotena didapati merosot paling tinggi iaitu sebanyak $113.54 \mathrm{ppm}$.
\end{abstract}

Kata kunci: minyak sawit mentah, rawatan haba, peratus pengekstrakan minyak, kualiti minyak, kestabilan minyak 


\section{Introduction}

Palm oil fruitlets are usually subjected to sterilization as a first step of the milling process. This process is carried out by steam sterilization of the bunches in sterilizers which are steam pressurized to as high as 40 psi at a temperature of $140^{\circ} \mathrm{C}$. The objectives of the sterilization process are to prevent free fatty acids (FFA) build up in the oil, soften the palm fruitlets and loosen the fruit on the bunch to facilitate stripping. It also helps to break up the oil bearing cells of the fruit mesocarp to release maximum oil during the digestion process [1]. After sterilization, the bunches are threshed in rotating threshers to detach the individual fruits. The detached fruits are then further soften and mashed in digesters, where the oil is extracted by screw pressing [2]. The crude palm oil is then clarified, purified and go through the oil vacuum dryer to be dried before it is stored in purified oil storage tank [3]. The conventional palm oil milling process as afore described does not involve solvent extraction. Instead, it is a combination of physical and mechanical approaches.

Strict quality control is practiced in the mill to ensure the least amount of deterioration of oil quality during the milling process. Fats and oils are graded by their acid and free fatty acid (FFA) contents, which are as an index to determine their quality. Palm oil contains about $45 \%$ of saturated palmitic acid and $39 \%$ of mono-unsaturated oleic acid [4]. Fatty acids play a very important role in fats and oils because of their health implications in the human diet and properties in industrial processes. The type of fatty acid determines the nutritional status and storability of the oil. Oil with higher levels of monounsaturated fatty acids such as oleic acid or polyunsaturated fatty acids such as linoleic or linolenic are more desirable for human consumption than saturated fatty acids. However, from the processing perspective, higher levels of polyunsaturated fatty acids contribute to oil oxidative instability, short shelf life, and rancidity

The conventional sterilization process also involves with high temperature, wet treatment and mechanical screw pressing which creating an environment favorable to the chemical and enzymatic reaction of hydrolysis including oxidation. Thus, researches have been done to look into the possibility of utilization of dry heating coupled with solvent extraction process. The influenced of heating time [2, $5-8]$ also has been investigated on the quality of crude palm oil (CPO). Solvent extraction and lower heating time was able to gives higher oil yield as well as good quality than conventional screw press. However, variations of time entail biochemical modifications of fat, which are explained by the variation of the free fatty acid and the degree of oxidation [6].

The aim of this research are to determine the effect of heating parameters of dry and wet heating process coupled with solvent extraction to increase oil yield as well as minimize the production of FFA and the oxidation of the fat. Stability of palm oil stored at room temperature after three months periods were also analyzed. Quality parameters measured were FFA, DOBI and carotene content to determined degradation by oxidation under these heating time conditions.

\section{Material and Methods}

All solvents and chemical used were analytical and chromatographic grades. Palm fruits were obtained from Palm Oil Milling Technology Centre (POMTEC) of Malaysian Palm Oil Board (MPOB) in Negeri Sembilan, Malaysia.

\section{Processing palm fruitlets: Experimental design}

Sterilization of oil palm fruits were carried out by studying the effects of heating temperature and time. In this study, oil palm fruits obtained from the mill were cleaned to remove any dirt on the surface followed by heated at required temperature and time under dry and wet condition using electrical oven (Memmert, UM 400, 1400 watt, $50 / 60 \mathrm{~Hz}$ ) and heating bath (Buchi B-490, 1400 watt, 50/60 Hz) respectively.

\section{Sterilization of oil palm fruits at different heating temperature and time}

Oil palm fruits were heated at 70,80 and $90^{\circ} \mathrm{C}$ for fix heating time at $90 \mathrm{~min}$. Meanwhile, oil palm fruit were heated at $90^{\circ} \mathrm{C}$ at different heating time of $30,45,60$ and $90 \mathrm{~min}$. 


\section{Oil yield}

The mesocarp of the fruits was peeled and the nuts were removed. The peel mesocarp were soaked in the hexane for $24 \mathrm{~h}$ at a solvent to fruit ratio of $1: 1(\mathrm{v} / \mathrm{w})$ and latter pressed using fruit press expeller. The extraction solution was filtered through a whatman filter paper No. 1. Solvent of the filtrate was then removed from the oil at $60^{\circ} \mathrm{C}$ via vacuum rotary evaporator. The yield of palm oil extract was determined using equation (1) below.

$$
\% \text { oil yield }=\frac{x}{y} \times 100
$$

where, $x$ is define as mass of oil extracted $(\mathrm{g})$ and $\mathrm{y}$ is defined as mass of oil palm fruits $(\mathrm{g})$.

\section{Physicochemical analyses of extracted oil: Chemical analysis}

Free fatty acid (FFA) content of the extracted oil was determined by using MPOB test method p2.5:2004 [9]. Sodium hydroxide solution $(0.1 \mathrm{M})$ was prepared and standardized with potassium hydrogen phthalate. A known mass of the oil sample was dissolved in neutralised iso-propanol and the free acids were neutralised with sodium hydroxide. FFA values were expressed as palmitic acid (\%). A mean value of duplicate samples was calculated.

Deterioration of Bleachability Index (DOBI) was also determined according to MPOB test method p2.9:2004 [9]. DOBI is defines as the ratio of the spectrometric absorbance at $446 \mathrm{~nm}$ to that $269 \mathrm{~nm}$. A known mass of the oil was dissolved in n-hexane in $25 \mathrm{ml}$ volumetric flask and dilute to the mark. The absorbance reading of the solution at $446 \mathrm{~nm}$ and $269 \mathrm{~nm}$ was taken using Hitachi U-2000 Spectrophotometer (Japan). A mean value of duplicate samples was calculated.

Carotene contents were carried using MPOB test method p2.6:2004 [9]. A known mass of the oil was dissolved in $\mathrm{n}$-hexane in a $25 \mathrm{ml}$ volumetric flask and dilute to the mark. The absorbance reading of the solution at $446 \mathrm{~nm}$ was taken using Hitachi U-2000 Spectrophotometer (Japan). A mean value of duplicate samples was calculated. The carotene content is expressed as ppm $\beta$ - carotene and is calculated as equation (2) below.

$$
\beta \text {-carotene }(\mathrm{ppm})=25 \times \frac{383}{100 \mathrm{~W}}\left(\mathrm{a}_{\mathrm{s}}-\mathrm{a}_{\mathrm{b}}\right)
$$

where, $a_{s}$ is define as absorbance of the sample $a_{b}$ is define as cuvette error and $w$ is define as weight of the sample in gram.

\section{Oxidative stability}

The rancimat method was used to determine oxidative stability by using a Metrohm 743 Rancimat. An amount $3.0 \mathrm{~g}$ of oil sample was prepared in a reaction vessel and placed in a heating block. The block temperature and air flow were set at $110{ }^{\circ} \mathrm{C}$ and $10 \mathrm{~L} / \mathrm{h}$ respectively. A mean value of duplicate samples was calculated.

\section{Fatty acid composition}

Fatty acid composition (FAC) was measured by conversion of the oil sample to their fatty acid methyl esters (FAME) according to the method described in MPOB test method (2004) with a minor modification. FAME was prepared by adding $50 \mathrm{mg}$ of oil into $6 \mathrm{ml}$ methanolic sodium hydroxide $(0.5 \mathrm{M})$. The mixture was heated on the steam bath for 10 minutes. $7 \mathrm{ml}$ of boron trifluoride methanol (20\%) was added and further heated for $2 \mathrm{~min}$ followed by $5 \mathrm{ml}$ of hexane and heated for $1 \mathrm{~min}$. The solution was removed from heat and $15 \mathrm{ml}$ of saturated sodium chloride solution was added to the solution. FAME was collected and dried over anhydrous sodium sulphate for 1 to 2 hours.

\section{Storage of palm oil extract}

Samples of oil extract from different heating time via wet heating were stored at room temperature with a temperature range of $28{ }^{\circ} \mathrm{C}$ to $32{ }^{\circ} \mathrm{C}$ for 3 months. Stability of oil was observed by measuring the changes in FFA, DOBI and carotene content. A mean value of duplicate samples was calculated. 


\section{Oil Yield}

\section{Results and Discussion}

\section{Effect of temperature}

The dependence of oil yield on temperature was determined at 70,80 , and $90{ }^{\circ} \mathrm{C}$ for fix heating time at 90 min. Figure 1 shows the effect of temperature on the oil yield. As expected, the oil yield was low at lower temperature. In this study, heating temperature of $90{ }^{\circ} \mathrm{C}$ is found to be adequate for optimum oil yield. Significant result is in agreement as reported by [10]. According to Baryeh [10] higher temperatures led to greater oil yield for both dry and wet heating process. Furthermore, results obtained suggested that the heating temperature should not be above $100^{\circ} \mathrm{C}$ for optimum yield. This is due to the increasing in yield was very small and also involving extra cost.

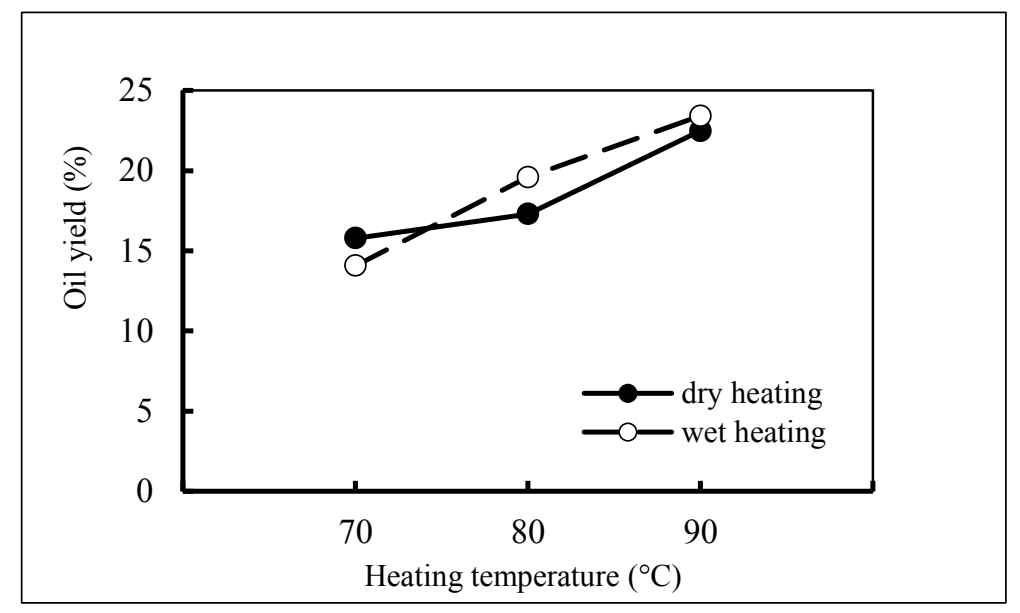

Figure 1. Effect of temperature on oil yield at heating time of $90 \mathrm{~min}$

\section{Effect of time}

Heat penetration is the key factor in sterilization of palm fruitlets. Inefficient penetration of heat supply leads to lower oil production. In addition, heating duration also played a crucial part in ensuring the heated fruit remained in good condition for subsequent oil extraction. The oil yield showed the efficiency of solvent extraction process and the effect of different heating duration on the oil content (Fig. 2). The results show that the oil yield increases with increasing duration time for dry $(18.86 \%-20.99 \%)$ and wet $(21.64 \%-24.55 \%)$ heating process. Higher oil yield was obtained when longer heating duration was used as more cell walls of the palm fruits had been ruptured due to heat generated. The results obtained were in good agreement with previous findings [5,6]. According to Malaysian Oil Palm Statistic in 2009, the average oil extraction rate from conventional sterilization and screw pressing in commercial palm oil mill was recorded as $20.21 \%$ [11].

Long heating duration caused the palm fruits to be overcooked and increment yield of burnt mesocarp. In contrast, moderate heating period giving a competent time to loosen the nuts from its mesocarp while keeping the yield high to reach the required standard as recommended by MPOB. Maximum oil yield of $24.55 \%$ was achieved at $90 \mathrm{~min}$ of heating time via the wet heating. However of all trials made, it was found that optimum range period of heating time was between 45 to $60 \mathrm{~min}$ via wet heating. Above $45 \mathrm{~min}$ heating time, the rise in yield nearly insignificant. 


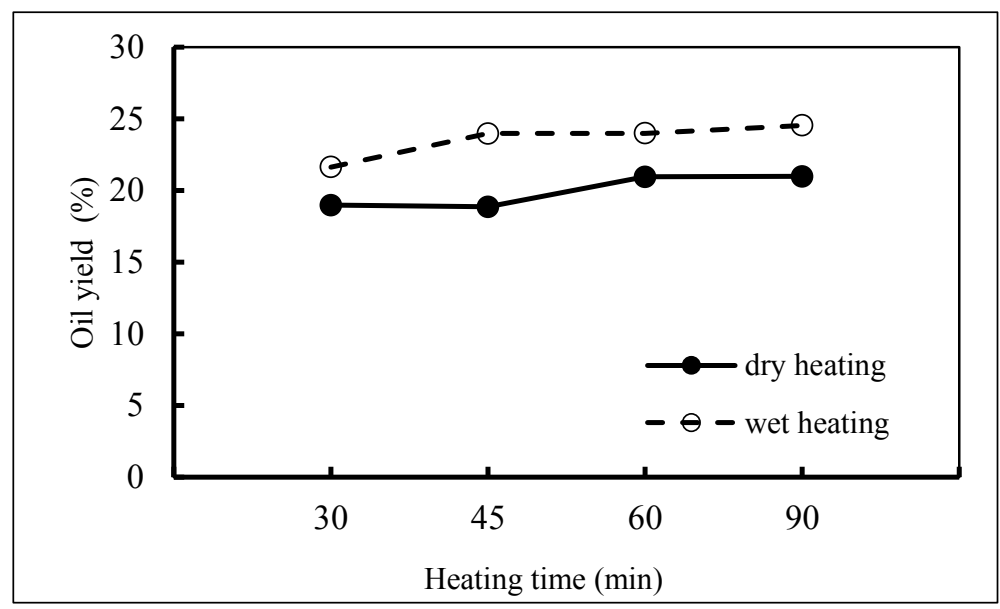

Figure 2. Effect of time on oil yield at heating temperature of $90{ }^{\circ} \mathrm{C}$

\section{Physicochemical analyses of extracted oil Chemical analysis}

Oil extracted from various heating time were selected to be further characterized. The quality of extracted oil using dry and wet heating are shown in Table 1. It is noted that oil extracted using the wet heating approach gave better quality compared to the dry heating. The results obtained from this study proposed the techniques used was able to produce better quality extracted oil set against the commercial CPO for all heating time used.

Table 1. Effect of heating time on oil quality

\begin{tabular}{|c|c|c|c|c|c|c|}
\hline \multirow{3}{*}{$\begin{array}{l}\text { Heating Time } \\
(\text { min) }\end{array}$} & \multicolumn{6}{|c|}{ Quality of Oil } \\
\hline & \multicolumn{2}{|c|}{$\begin{array}{l}\text { FFA } \\
(\%)\end{array}$} & \multicolumn{2}{|c|}{ DOBI } & \multicolumn{2}{|c|}{$\begin{array}{c}\text { Carotene Content } \\
(\mathrm{ppm})\end{array}$} \\
\hline & Dry & Wet & Dry & Wet & Dry & Wet \\
\hline 30 & 4.97 & 1.20 & 4.52 & 6.25 & 595.31 & 806.78 \\
\hline 45 & 2.45 & 1.15 & 5.21 & 5.57 & 588.98 & 791.76 \\
\hline 60 & 2.37 & 0.93 & 6.06 & 6.10 & 846.09 & 938.42 \\
\hline 90 & 1.42 & 0.99 & 6.09 & 5.42 & 930.01 & 763.10 \\
\hline Commercial CPO & \multicolumn{2}{|c|}{$<5.0^{\mathrm{a}}$} & \multicolumn{2}{|c|}{$>2.8^{\mathrm{b}}$} & \multicolumn{2}{|c|}{$500-700^{c}$} \\
\hline
\end{tabular}

${ }^{\mathrm{a}}[19] ;{ }^{\mathrm{b}}[20] ;{ }^{\mathrm{c}}[21]$

FFA value was gradually decreased as the duration of the heating time was increased for all the heating time. This is due to termination of hydrolysis enzyme in fruits. The lowering of FFA content hence contributed to higher DOBI value. Unfortunately, this situation not helping in increasing the carotene content. Therefore, both FFA and DOBI values gave no effect on the carotene content.

\section{Unsaturated fatty acids contents}

The TAG in palm oil partially defines most of the physical characteristics of the palm oil such as melting point and crystallization behavior [12]. Figure 3 shows the unsaturated fatty acid composition for both dry and wet heating process. Unsaturated fatty acid content slightly drops with the time after $60 \mathrm{~min}$ exposure, due to long term heating 
duration. The composition of fatty acid obtained was within the reported range for all heating duration used. The ranges for unsaturated fatty acid in commercial crude palm oil (CPO) is between $47.5 \%-51.8 \%$ [4].

Lower unsaturated fatty acid was obtained when longer heating duration was applied as more cell walls of the palm fruits had been ruptured due to heat generated. Similar observation was also observed by Macaire et al. in their study of kernel oil [13]. Owolarafe et al. [14] reported similar results when they studied the micro-structural characterization of palm fruit.

The oil extracted show narrow range in unsaturated fatty composition for dry and wet heating processes (with different only $0.11 \%-2.33 \%$ ). Oil extracted from wet heating show lower unsaturated fatty acid content compared with dry heating process. Wet heating process possesses water to facilitate rupturing of oil cells and destruction of the cell wall [14]. Thus their unsaturated fatty acids fix oxygen and oxidize easily.

The slightly higher content of fatty acid for dry heating compared to wet heating was due to this fatty acid remains trapped in cells. Heat penetration of dry heating was not efficiently penetrated into the fruit but only the outer surface of the fruit. Increases in heating time thus hardened the mesocarp and reduce the chances of the disintegration of the cell content, consequently blocking site from exposing to oxygen and the enzymes to attack double bond.

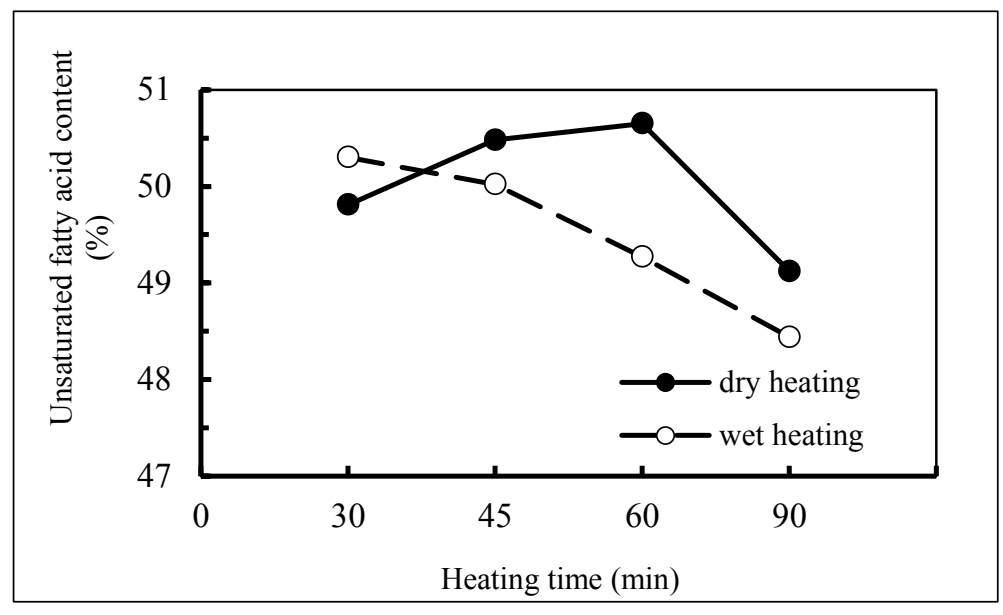

Figure 3. Content of unsaturated fatty acids at various heating time

\section{Oxidative stability}

Rancimat test is usually carried out to determine the oxidative stability by considering the Rancimat induction period (RIP). The RIP values represent the stability of the sample. The greater the RIP value, the sample is less susceptible towards oxidation [15]. Figure 4 shows the oxidative stability for both dry and wet heating process varied between $20.56-26.87 \mathrm{~h}$. Oxidative stability (RIP) in CPO is $>25$ hours [15].

In this study, heating duration less than 45 min did not achieve comparable RIP to that of commercial CPO. Higher RIP (25.51 - 26.87 hours) was obtained after 45 and $60 \mathrm{~min}$ of heating duration. This result showed that oxidative stability increased with increasing heating duration. At 60 min of heating, the oil extracted from dry and wet heating recorded the highest oxidative stability.

During the heating time, oxidative stability increases due to heating assistance to break the cellular membrane of the fruit mesocarp. In this study, results shows the wet heating has higher oxidative stability compared to dry heating 
process. The findings relatively significant to the results obtained from unsaturated fatty acid and FFA content respectively (Figure 3 and Table 1).

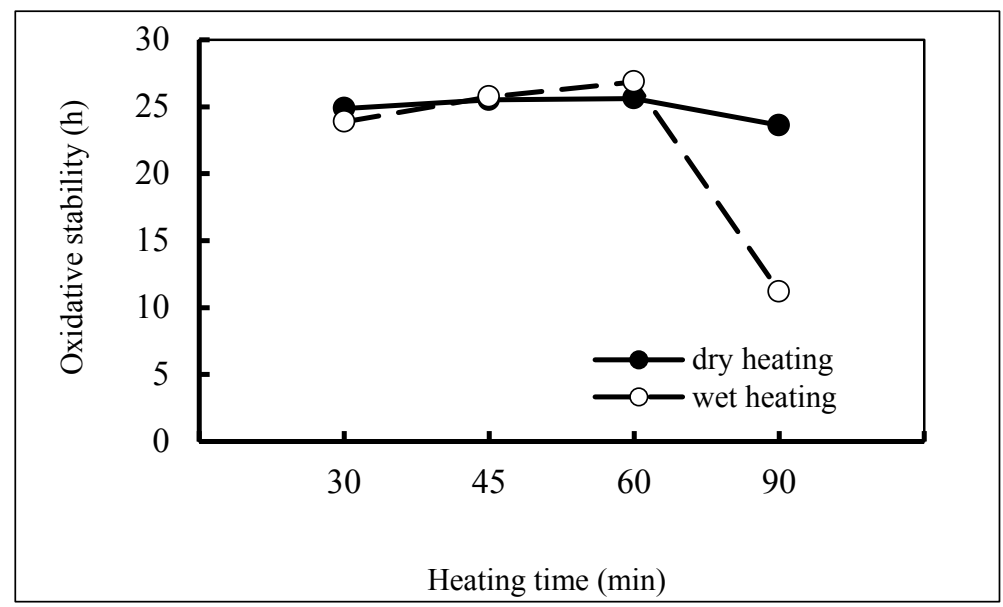

Figure 4. Oxidative stability of oil extracted at various heating time

\section{Storage stability}

It is essential to any palm oil mill to extract CPO with excellent quality and stability. The oil stabilities during storage are vital parameter for ensuring that oil appears the good performance at elevated temperature. Table 2 shows the initial value of FFA, DOBI and carotene content for dry and wet heating process before storage at room temperature. For all heating time used, dry heating process gives higher value of FFA compared to wet heating process therefore higher deterioration. Thus, oil sample from wet heating process will produce better quality storage oil in terms of lower FFA content.

Table 2. Initial value of FFA, DOBI and carotene content in palm oil extract at different heating time

\begin{tabular}{lccccccc}
\hline & \multicolumn{9}{c}{ Quality of Oil } \\
\cline { 2 - 8 } $\begin{array}{l}\text { Heating Time } \\
\text { (min) }\end{array}$ & \multicolumn{2}{c}{$\begin{array}{c}\text { FFA } \\
(\mathbf{\%})\end{array}$} & \multicolumn{3}{c}{ DOBI } & \multicolumn{2}{c}{$\begin{array}{c}\text { Carotene Content } \\
\text { (ppm) }\end{array}$} \\
\cline { 2 - 9 } & Dry & Wet & Dry & Wet & Dry & Wet \\
\hline 30 & 2.49 & 2.36 & 3.17 & 3.79 & 754.13 & 746.09 \\
45 & 2.64 & 2.24 & 2.40 & 3.64 & 762.09 & 779.65 \\
60 & 2.17 & 1.95 & 3.03 & 3.65 & 762.80 & 880.60 \\
90 & 2.03 & 1.44 & 3.23 & 3.49 & 717.87 & 710.20 \\
\hline
\end{tabular}

Figure 5 shows the changes in quality of palm oil extracted at different heating time via wet heating. The quality of extracted oil was determined before and after 3 months storage at room temperature. After 3 months storage, 60 min of heating time recorded the lowest increment of FFA, 1.32 as well as lowest reduction of DOBI value, 0.41. This finding was due to higher initial carotene content that helps to decrease the rate of oxidation or prolong the induction period by interrupting the oxidation reaction. However, it suffers the highest loss of carotene content, 
$113.54 \mathrm{ppm}$ towards the end of storage. Similar findings of carotene content loss have been reported by Noor Akhmazilla et al. [8].
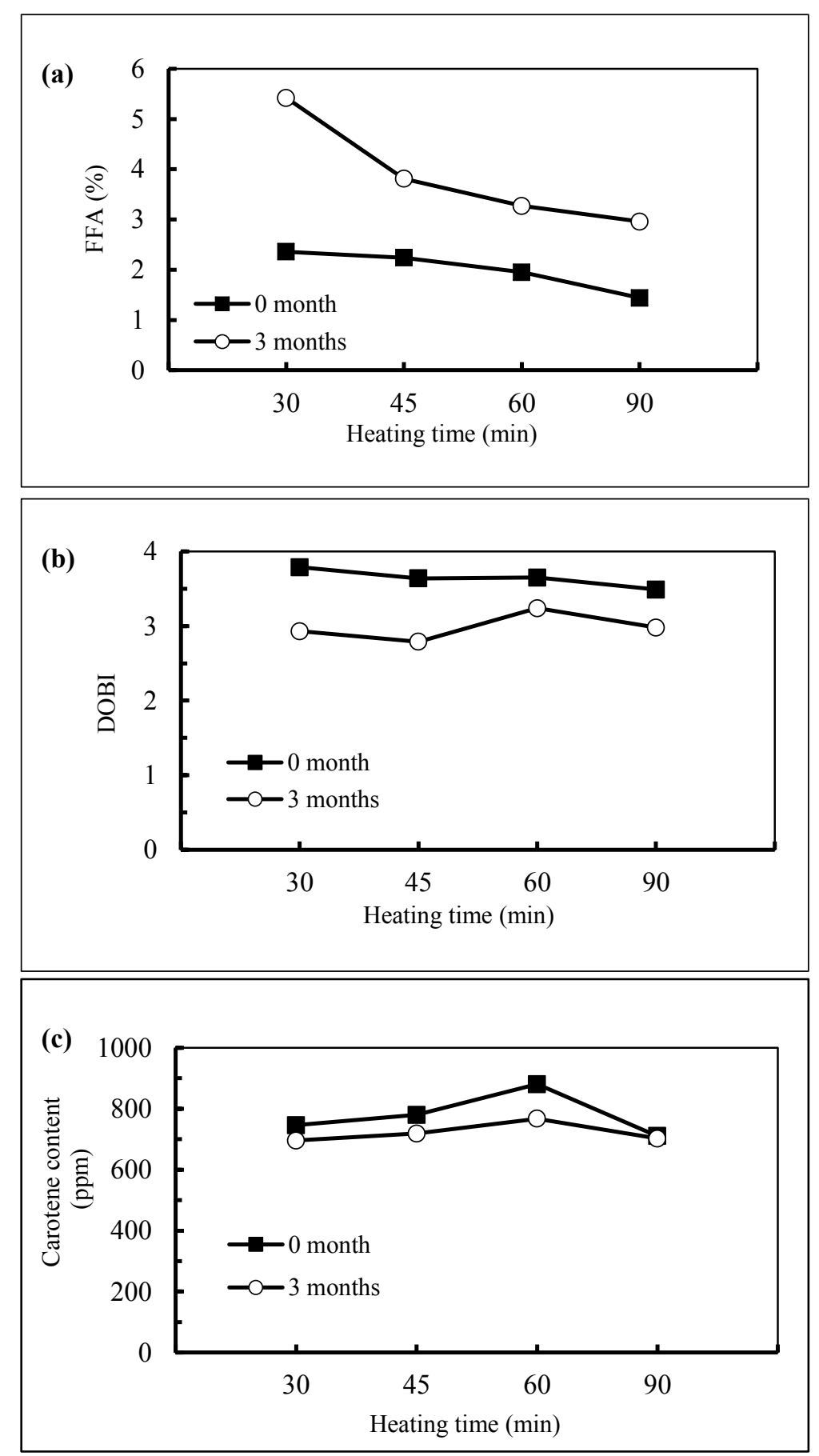

Figure 5. (a) FFA (b) DOBI and (c) Carotene content of extracted oil via wet heating before and after 3 months storage 


\section{Conclusion}

Heat treatments during sterilization process are an important factor in determining oil yield and quality of extracted oil. This study showed that the temperature and time gave effect on the yield of extracted oil. Wet heating gives higher oil yield than dry heating process. However, dry heating and wet heating process had little effect on quality of extracted oil. This study has revealed that heating temperature at $90{ }^{\circ} \mathrm{C}$ and heating time at 60 min via wet heating extract higher oil yield, better CPO quality and good storage stability. The oil extraction yield can be further increased by optimizing other extraction technique. Other quality parameters could also be measured to support the efficiency of the heat treatment used during sterilization.

\section{Acknowledgement}

The authors like to thank the Director General of MPOB for financial support and Universiti Kebangsaan Malaysia (UKM) for supporting this work. Thanks also to the Engineering and Processing Division for laboratory facilities as well as from Advanced Oleochemical Technology Center for quality analysis.

\section{References}

1. Mahidin, M. R. (1998). Quality improvement in the production of Malaysian palm oil. Palm Oil Development, 9: $15-21$.

2. Chow, M. C. and Ma, A. N. (2007). Processing of fresh palm fruits using microwaves. Journal of Microwave Power \& Electromagnetic Energy, 40 (3): 165 - 173.

3. Ariffin, A. A. (1991). Chemical changes during sterilization process affecting strippability and oil quality. In Seminar on Developments in Palm Oil Milling Technology and Environmental Management: pp. 2 - 12.

4. PORIM (1991). International Palm Oil Conference Chemistry \& Technology. pp. 269.

5. Cheng, S. F., Mohd Nor, L. and Chuah, C. H. (2011). Microwave pretreatment: A clean and dry method for palm oil production. Journal of Industrial Crops and Products, 34: 967 - 971.

6. Nu'man, A. H., Ng, M. H., Choo, Y. M. and Ma, A. N. (2012). Dry heating of palm fruits: Effect on selected parameters. American Journal of Engineering and Applied Sciences, 5(2): 128 - 131.

7. Mohd Fauzi, N. A., Sarmidi, M. R. and Chua, L. S. (2011). Metabolites profiling of heat treated palm oil extract. Journal of Applied Sciences, 11(13): 2376 - 2381.

8. Mohd Fauzi, N. A. and Sarmidi, M. R. (2011). Extraction of heat treated palm oil and their stability on $\beta$ carotene during storage. Journal of Science and Technology, 2(1): 45 - 54.

9. Malaysian Palm Oil Board (2004). MPOB Test Methods. Malaysian Palm Oil Board, Ministry of Primary Industries, Malaysia.

10. Baryeh, E. A. (2001). Effect of palm oil processing parameters on yield. Journal of Food Engineering, 48(1): 1- 6 .

11. Malaysian Palm Oil Board (2010). Malaysian Oil Palm Statistic 2009. Kajang. Malaysia.

12. Sambanthamurthi, R., Sundram, K. and Tan, Y. A. (2000). Chemistry and biochemistry of palm oil. Progress in Lipid Research, 39: 507 - 558.

13. Macaire, W. H., Bernard, T., Noel, T., Felicite, T. M., Cesar, K., Michel, L. and Jacques, F. (2010). Extraction of palm kernel oil in Cameroon: effects of kernels drying on the oil quality. Journal of Food Technology, 8(1): $1-7$.

14. Owolarafe, O. K. and Faborode, M. O. (2007). Micro-structural characterisation of palm fruit at sterilisation and digestion stages in relation to oil expression. Journal of Food Engineering, 85: 598 -605.

15. Yung, C. L., Choo, Y. M., Cheng, S. F., Ma, A. N., Chuah, C. H. and Yusof, B. (2006). The effect of natural and synthetic antioxidants on the oxidative stability of palm diesel. Fuel, 85: $867-870$.

16. Noraini, S. and Siew, W. L. (1990). Quality control measures in palm oil industry. Palm Oil Dev.

17. Vijaya, S., Choo, Y. M., Muhammad, H., Hasyim, Z. and Yew, A. T. (2010). Life cycle assessment of the production of crude palm oil (part 3). Journal Oil Palm Research, 22: 895 - 903.

18. Chong, C. L. (1994). Chemical and physical properties of palm oil and palm kernel. Selected readings on palm oil and its uses. Malaysia: Palm Oil Research institute of Malaysia: pp. 60 - 67. 